\title{
THE IMPORTANCES OF TELUK ANSON WHARF AS TRANSIT CENTRE OF MERCHANT VESSEL, 1882-1941
}

\author{
Bipin A/L Babulal ${ }^{1}$ \\ Postgraduates, History Department, \\ Faculty of Human Science, Universiti Pendidikan Sultan Idris \\ (Email: bipinbab@swiftlogistics.com.my) \\ Khairi Ariffin ${ }^{2}$ \\ Assoc. Professor, History Department, \\ Faculty of Human Science, Universiti Pendidikan Sultan Idris \\ (Email: khairi.ariffin@ fsk.upsi.edu.my)
}

Accepted date: 23-04-2019

Published date: 10-07-2019

To cite this document: Babulal, B., \& Ariffin, K. (2019). The Importance of Teluk Anson Wharf as Transit Centre of Merchant Vessel, 1882-1941. International Journal of Heritage, Art and Multimedia, 2(5), 72-79.

DOI: $10.35631 /$ ijham.25006

\begin{abstract}
This study is about the importance of the Teluk Anson wharf which used to be the transit centre of the merchant vessel in 1882 until 1941. It also was known as wharf in the British colonial administration since the opening in 1882. The development and construction of Teluk Anson port is very important as a wharf which handle the import and export transactions in the state of Perak, especially as the collection centre of tin ore and agricultural product for the districts of Lower Perak and other nearby places. The study is carried out by using the qualitative method which focusing the analysis on the primary sources such as Marine Annual Report, Federated Malays States Annual Report, Perak Annual Report, District Report and Perak Secretariat File which obtained from The National Archive of Malaysia. The study is focusing on the Teluk Anson wharf that located in the district of Lower Perak. The findings show that the port of Teluk Anson had significant role in trading activity, export and import of merchandise especially after commercial agricultural revolutions. The wharf of Teluk Anson became the focus of the merchant vessels from the Malay States, Southeast Asia, Europe and the United States. In conclusion, the infrastructural facilities which existed in the Teluk Anson wharf towns made this wharf as the main attraction in the Federated Malay States at the early of its opening until the World WarII. The implication of this study shows that the Teluk Anson wharf used to be the important wharf in the state of Perak during British colonial era.
\end{abstract}

Key Words: Vessels, Development, Construction, Infrastructure

\section{Introduction}

The British administration in Perak which began in 1874 was created the new forms of aspects in trade economic activity. This includes the effort of British colonial to create an important wharf which as the main center of maritime trade activity. The development of ports and wharf was a result of European colonization since the Portuguese rule in Malacca 
and expanded to other states until the British administration in the Federated Malay States (Nordin Hussin, 2002). Prior to the arrival of the British colonialism, the maritim area of the of the South China Sea and the Malacca Straits used to be an impotant maritime-based trade. In addition, it has also been the water route between communities in Southeast Asia as well as trade routes for traders dealing with India and China (Mohd Samsudin et al, 2011).

Among the most important ports of Federated Malay States is located in Teluk Anson. The town of Teluk Anson has been categorized as a rapid-developing region. This was based on the observations made by Governor Sir Frederick Aloysious Weld who acted as Governor of the Straits Settlements in 1880 until 1887 during a brief meeting with Mr. Denison who was the Lower Perak Superitendant and the Malay authorities (Straits Settlement Annual Report, 1884). Teluk Anson was once known as a prosperous and growing city although it was originally composed of a thick forest area (Swettenham F.A.,1893). The town of Teluk Anson also serves as the Lower Perak railway station which serves as a main place of the collection of agricultural and mining products in Lower Perak and the district nearby. The activity causes the Teluk Anson town became the main place of economic trade activities which use railways services for the purpose of transporting the merchandise such as tin and rubber.

\section{Problem Statement}

The Teluk Anson Port was known as wharf during the British administration since its opening in 1882. Starting in 1896, the operation of Teluk Anson wharf was under the Federated Malay States Railways (FMSR). The development and construction of the Teluk Anson wharf was very important as a port which manage the import and export transactions in the state of Perak, especially as a center for the collection of tin and agricultural products of the Lower Perak district and the nearby district. The wharf of Teluk Anson also became a focus for local traders because prior to the construction of the wharf, they used Kuala Sungai Bidor as the main port.

In addition, the wharf of Teluk Anson was also the main focus of ships from Malaya, Southeast Asia, Europe and America. Its role was getting growing and important and also became among the major ports in the Federated Malay States other than Port Weld and Port Swettenham. The port has been moved from the original site to a new site of one mile distance from the downstream to overcome erosion problems and expanded the provision of infrastructure and logistics facilities to provide better services of trading.

\section{Objective}

This study will gain three main objectives

i. Study the background of Teluk Anson wharf opened in Lower Perak.

ii. Analyze the role of Teluk Anson Wharf in economic development in Lower Perak.

iii. Assess the importances of Teluk Anson Wharf in Lower Perak.

\section{Literature Review}

Prior to the arrival of British colonials in the Federated Malay States, the existence of ports had played an important role in trading activities on the coastal waters and also involvement of trading with other countries. According to Nordin Hussin (2001) in an article titled, Tale of Two Colonial Port-Towns in the Straits of Melaka: Dutch Melaka and English Penang has explained the comparison between ports in Malacca during the Dutch conquest and port in Penang during the British occupation of the state. The author has described the features of the 
Dutch and British colonial ports in Melaka and Penang. Both port cities were deemed to have western-oriented elements and environments such as camps and church buildings. This study is more focused on the development of towns in the ports of Melaka and Penang during the Dutch and English era. The development of trading activities as well as ports is only described in the basic and general.

Generally, Nordin Hussin's study is more extensive and comprehensive compared to this study which is more focused on the interests of Teluk Anson wharf and trade activities through various shipping companies. However, Nordin Hussin's study illustrates the situation of urban development as a result of major harbor activities in Malacca and Penang as well as facilitating studies in identifying the importance of ports in the Malay states in general. Thus, this study was more focused on the major ports of the Federated Malay States and its developments during the British colonial era.

The role of the port is also explained by Wayte M.E (1959) in an article titled Port Weld. This study emphasizes the development history and role of Port Weld since its establishment in 1885. At the early of its establishment, Port Weld or also known as port of Kuala Sepetang was the main place of tin ore collection obtained from Taiping, Kamunting and Larut. However, the study was focusing on the role and development of Port Weld only and there is no explanation regarding to the wharf of Teluk Anson. Wayte's writing has provided a preliminary portrayal of Port Weld's interests and helps get information on the history of the establishment of an important port in the state of Perak. Although Wayte's research was inspired by history and development in Port Weld, but an overview of the role of a port as a trading center and ship stopover has helped in identifying the importance of the wharf of Teluk Anson.

The port activities in the East Coast of Malaya were described in article writings entitled Perkembangan Pengangkutan Marin Sekitar Pantai Timur Tanah Melayu Zaman Tradisional dan Zaman Pentadbiran British by Mohd Samsudin et al (2011). The article was focusing on the development and port activities in Pulau Tioman, Pekan and Kuala Terengganu which were the main focus of traditional trade vessels in the east coast of Malaya during British colonial administration. In addition, the study has emphasized that maritime and port activities continue to grow starting from the traditional until the British colonial era. Although the discussion was focusing on the wharf development in the east coast of Malaya, it has helped to illustrate the British administration's policy and the wharf function as a trade center.

The article titles Teluk Anson: 1882-1941: Port, Agriculture and Erosion by Khoo Kay Kim (1995) was more about the indentity of the town of Teluk Anson that has an important role as a port and agricultural area. The role and development of the wharf of Teluk Anson was descibed basically and was focusing on the erosion issues occurring at thee estuary of Teluk Anson wharf. In addition, the study is more about the development of major agriculture and crops in the district of Lower Perak and the town of Teluk Anson. However, explaination on agricultural developments has shown that the role of the port also depended on the development of agricultural activities since the crop has been collected at the wharf of Teluk Anson before being exported. Hence, the article also illustrates that agriculture is one of the important import and export items that has been carried out at the port of Teluk Anson. 


\section{Research Methodology}

The study was carried out entirely using qualitative methods which focusing on the approaches of document analysis such as Perak Secretariat File, Federated Malay States Annual Report of Railways, District Report and Marine Annual Report which obtained from National Archived of Malaysia. Critical research and analysis of the files or documents has been done to obtain the accurate data. Secondary reference sources such as books and writings relating to the construction of roads and railways networks in Perak and the Federated Malay States during British colonial administration were also used to strengthen the finding of the study.

\section{Finding}

When the district of Lower Perak was under the administration of Captain Speedy in 1877 who acted as the Assistant Resident, a village of Durian Sebatang in Teluk Anson has no facilities and infrastructures but some only small ditch with muddy ground and quite impassable for wheeled vehicles (Sadka, E ,1955). The road was quite narrow and has a 12feet wide roadway. In 1879, when Lord Archibald Anson who acted as the Governor of the Straits Settlements, used to build the Teluk Anson town development plan. Among the planned developments during the Lord Archibald Anson's administration in the Straits Settlement was to develop a wharf in Teluk Anson. The construction of railway routes for passengers and merchandises which connecting Teluk Anson to Tapah Road and connected to Ipoh was influenced the expansion of Teluk Anson's wharf role. In addition, the construction of the railway line at the wharf of Teluk Anson has also been a factor that promotes the development of Teluk Anson town as a port city. As a result of the development plan of Lord Archibald Anson, Teluk Anson continues to lead the role of a major port in the state of Perak.

The entrance to the Perak River has a good lighting control system and a the trade vessels from Penang and Singapore were docked to Teluk Anson almost every day (Swettenham, F.A., 1893). Teluk Anson wharf also plays an important role as a stopover for merchant vessels which carrying food, oil and petroleum products, rubber, tin and copra (Annual Report on Social and Economic Progress, 1947). The vessels service was also used as a water transport for the passengers who were heading to Singapore and Penang as well as using train transportation services.

The Teluk Anson Port was once serves as vessel's anchorage from the Straits Steamship Company which included cargo items involving three ports, Teluk Anson, Melaka and Singapore (Government Secretary 2471/91, 1891). Ships from Singapore's Straits Steamship Company operate daily and sailed from Singapore's port to Teluk Anson and return to Malacca. Straits Steamship Company is the dominant shipping company in maritime trades of Malaya including in the port of Teluk Anson (Ooi Jin Bee,1963). The company was founded on January 20, 1890 and used to known as The Straits Navigation Company (Mohd Samsudin et al,2011) Since the 1890s, ships from The Straits Steamship Company have begun to land at the wharf of Teluk Anson and sailing to Port Swettenham and Singapore. In addition to cargo or transporting the merchandise, the vessels from the company also carried the passengers to Singapore port at $\$ 12$ per person in first class including food packages, $\$ 6$ per person for passengers sitting in second class and $\$ 3$ per person on the deck of the vessel (Government Secretary 2471/91, 1891). The peoples use this marine transportation services as one of the alternative connectivity networks besides the service of the railway or the road especially to Selangor, Malacca and Singapore. 
In 1891, Straits Steamship Company got a contract to bring equipment for the construction of Kinta Valley Railway from European countries. All of this equipment were brought to Singapore's contractors and sent directly to the wharf of Teluk Anson. The government or the Federated Malay States Railway has been obliged to provide steam-winch (a revolving steam-powered machine to move the heavy loads) to transport equipment from ships with a capacity of 2.5 tonnes or equivalent to $2268 \mathrm{~kg}$. Every $28 \mathrm{lbs}$ of goods lifted was charged 40 cents and items over $2981 \mathrm{bs}$ and not exceeding $56 \mathrm{lbs}$ was charged 75 cents. Therefore, the Straits Steamship Company were authorized to land at the wharf of Teluk Anson if the maintainances work was required on the vessel for at least seven days.

The importance of Teluk Anson as one of the harbors in the state of Perak is also influenced by the existence of the Tapah railway route to Teluk Anson which was completed in 1893 (Government Secretary 2471/91, 1891). The development of Teluk Anson's as an important wharf was due to being one of the main wharfs of trading activity. The steam powered vessels were anchored in quite long term along the shore and would sailed after the cargo loading was completed (The Straits Times, 1895). This caused the Teluk Anson marine traffic became congested with shipping activities. However, the construction of railway routes has affected the owners of small boats, especially the Malays who usually carry the merchandise by using their boats from Teluk Anson to the Kinta district (Khoo Kay Kim, 1995). Most traders and entrepreneurs make their boats as a home on the water. It also affected the income of the villagers who used to serve their boats as perahu penambang.

But in 1901 there were problems involving the physical transformation of the Teluk Anson wharf area. The port area of Teluk Anson has been subjected to a problem following the erosion of its products (Khoo Kay Kim, 1995). In order to prevent the erosion, the jetty has been moved to a safe and suitable location for the development of a city. The new wharf area was about a mile along the Batak Rabit road (Khoo Kay Kim, 1995). Beside the Port Weld, the trade activity in the state of Perak and foreign countries was through the wharf of Teluk Anson. The trade's revenue was estimated to be twenty million dollars annually including collection of voyage fees (Swettenham, F.A., 1893) The high returns allowed the wharf management to provide a lodging facility to outsiders who have stopped at Teluk Anson wharf before continued the sailing.

During the construction of the new Teluk Anson station and jetty beginning in 1907, the implementation of other structures and facilities was also developed (Perak 269/1907, 1907). Among them was the railway extension from Teluk Anson station to the new jetty site. The road also built to facilitate the movement to the jetty. Whereas storage of the merchandises before being transported by boat was covered by roofs for the safety purpose (Perak 269/1907, 1907). The 700-yards roadway to the station was also built as one of the wharf infrastructure improvement processes (Annual Report on Federated Malay States Railways, 1907). Teluk Anson wharf management also receives $\$ 70,000$ for infrastructure improvements in the wharf area. In addition, the shed facility of 132'x48'6 "was built near the wharf as one of the waiting areas. A new pontoon structure with two gangways was also built. The 700-meter roadway from the wharf area is also paved to facilitate the passage of the vehicle and the loading of goods from the vehicle to the wharf. The upgraded new facility has led to the rapid expansion of commercial activities in the wharf area for the purpose of transporting goods and mining boat services. The use of lamps in the lighthouse which originally used oils has been converted into automatic lighting lighting which was suited to the crowded wharf conditions (Perak Adminstration Report, 1930). 
Besides the trades activity, boat rental services were also carried out by merchants and sailors who had their own boats (Perak Adminstration Report, 1930). According to records in the Perak Administration Report 1930, there were 48 motorized boats through the Bernam River and the Perak River and heading to the wharf of Teluk Anson. In 1930, the water transport service by the connecting boat between Bangkok and Teluk Anson was introduced by Hung Phong Company of Bangkok. Once every two weeks, the Teluk Anson wharf receives rice delivery from Bangkok by the vessels from the company. Trade relations between Perak and Bangkok existed during the colonial period indicated that the British administration was concerned with good relations and trade with regional countries.

The marine maintenance work also was carried out at the Teluk Anson wharf during the British colonial era. The maintenance work of the Telok Anson jetty was carried out by the Public Work Department around 1946. Based on reports from Telok Anson's Harbor Master Office, the physical condition of the jetty at Telok Anson including small boats needs improvement. The wharf at was generally in unsatisfactory condition. The construction of this new rest house has shown the importance of Teluk Anson which has been the focus of external officials and visitors due to the existence of farms cultivated around the district.

Telok Anson wharf is also a center for export and import of rubber products (High Commisioner Office 1442/1915, 1915). In 1915, the United States and France were among the shipping destinations for shipping through the shipping service and the cruise ship destination started at the port of Teluk Anson. Rubber delivery in 1915 was approved by the Rubber Export Committee to be sent to designated locations such as Boston, New York, Cenon and Marseillis (High Commisioner Office 1442/1915, 1915).

Harbor Master or head of Teluk Anson wharf, Flight Millard was carried out his duties in conducting surveillance and inspection of the surrounding ports. The effects of damage during the Japanese occupation during the Second World War were also interrupted during the jetty under his supervision (Technical Services Com 58/7). After the port overhaul, Asiatic Petroleum Company's Installation and Jetty was constructed in early 1947 aimed at transferring petrol fuels in bulk (Annual Report on Social and Economic Progress, 1947). Construction of this new jetty has made petrol fuel transfer activities more practical and safer. Among the fuel firms that make the Teluk Anson port as an oil storage terminal were Shell Company and Standard-Vacuum Oil Company, which is owned by Anglo-Saxon Petroleum Company from the Netherlands. The existence of petroleum companies was helped in highlighting the interests of the Teluk Anson wharf as an anchorage location for the trading vessels.

In terms of ownership of vessels and licenses, each ship or boat owner or operator needs to register a license for anchoring at Teluk Anson port. Table 1 below shows the license that has been registered by the shipowner involved.

Table 1: Amount of Registered Licences

\begin{tabular}{cc}
\hline Type of Boat / Ship & Amount of Registered Licenses \\
\hline Small Vessels & 1,703 \\
Cargo Boats & 1,000 \\
Sampan & 407 \\
Motor Cargo Vessels & 166 \\
Passenger Boats & 118 \\
Sailing Junks & 12 \\
\hline
\end{tabular}




\section{Total}

Source: Perak Annual Report of Social and Economic Progress

Table 1 shows the number of vessel licenses in the registered port of Teluk Anson. The number of registered small boat licenses shows the highest number of 1703 units and followed by cargo boats with a total of 1,000. The number of licenses for boat serving 407 passengers and 166 licenses registered by motor-powered cargo ships. The number of licenses registered by the passenger boat is 112 and is followed by the number of licenses registered by the yacht owner.

The development of the wharf functions at Teluk Anson also encouraged the development of transport network links. Transportation facilities have also become one of the factors of the town development of Teluk Anson. The wharf development in Teluk Anson was also a symbol of a new economic transition especially in the downtown area of Perak (Lim Heng Kow, 1978). This is due to the demand for raw materials supply to further promote the export of commodities or raw materials and indirectly the wharf of Teluk Anson was becoming a main focus of trade vessels from the Malay states and abroad.

\section{Conclusion}

In conclusion, the infrastructural facilities that existed in the wharf and Teluk Anson towns was made this wharf an important attraction in the Federated Malay States at the beginning of its opening until the second world war. The presence of the Teluk Anson wharf was closely related to the construction of the second railway in Malaya, the Tapah route to Teluk Anson. Overall, this study shows that the port of Teluk Anson was a very important wharf in the state of Perak during the British colonial era and contributed to the economic development of the state of Perak.

\section{References}

Annual Report Social And Economic Progress 1947.

Annual Report on The Federated Malay State Railways, 1907.

Government Secretary 2471/91, Forward Copy of a Entered into by This Government with The Straits SteamShip Company, 1891

HCO 1442/1915, Rubber Shipment 1915

Khoo Kay Kim. (1995), Teluk Anson:1882-1941:Port, Agriculture and Erosion. Journal of Malayan Branch of the Royal Asiatic Society. Vol 68(2). pp33-52

Lim Heng Kow. (1978), The Evolution of Urban System in Malaya. Kuala Lumpur: Penerbit Universiti Malaya.

Mohd Samsudin, Azima Abd Manaf, Shahizan Shaharudin. (2011), Perkembangan Pengangkutan Marin sekitar Pantai Timur Tanah Melayu Zaman Tradisional dan Zaman Pentadbiran British. Journal of Tropical Marine Ecosystem. pp. 30-42

Nordin Hussin. (2002), A Tale of Two Ports Towns in the Straits of Melaka: Dutch Melaka and English Penang, Journal of Malaysian Branch of the Royal Asiatic Society. vol 75(2), pp 65-98

Ooi Jin Bee, 1963, Land, People and Economy in Malaya. London: Longmans, Green and Co Ltd

Perak 269/1907, New Station and New Wharf at Teluk Anson.

Perak Administration Report, 1930

Sadka, E. (1955), The Journal of Sir Hugh Low, Journal of Malayan Branch of The Royal Asiatic Society, Vol 27(4). Hlm 88.

Swettenham, F.A. (1893), About Perak. Singapore: The Straits Times. 
Straits Settlement Annual Report ,1884

Technical Services Com 58/7, Report on Local Condition Marine (Peninsula)

The Straits Times 19 July 1895

Wayte, M.E. (1959), Port Weld. Journal of the Malayan Branch of the Royal Asiatic Society. Vol 32(1). Pp 154-167 